\title{
Holocene vegetation history of the southern Levant based on a pollen record from Lake Kinneret (Sea of Galilee), Israel
}

\author{
Vera Schiebel ${ }^{1} \cdot$ Thomas Litt $^{1}$ (D)
}

Received: 26 June 2017 / Accepted: 22 November 2017 / Published online: 14 December 2017

(c) The Author(s) 2017. This article is an open access publication

\begin{abstract}
Lake Kinneret, also known as the Sea of Galilee and Lake Tiberias, is located in the northeast of Israel. At a lake level of $211 \mathrm{~m}$ b.s.l. (below mean sea level), the central basin is $43 \mathrm{~m}$ deep. The maximum length of the lake is $21 \mathrm{~km}(\mathrm{~N}-\mathrm{S})$ and its maximum width is $12 \mathrm{~km}(\mathrm{~W}-\mathrm{E})$. Lake Kinneret's surface area is $166 \mathrm{~km}^{2}$. A new $17.8 \mathrm{~m}$ long sedimentary core was drilled in 2010. Here, we present the entire palynological record from it, which covers the last $\sim 9,000$ years. Special emphasis is given to the natural and human-influenced vegetation history of Galilee in comparison to that of the more southerly Dead Sea region. Significant signs of human impact are the first Olea (olive) increase during the beginning of the Chalcolithic period between 7,000 and 6,500 years ago, as well as the prominent Olea phase during the Hellenistic/Roman/Byzantine period between 2,300 and 1,500 years ago. Mediterranean macchia and bathas scrub vegetation, as known in the area today, has developed in the southern Levant under human impact since the last ca. 1,500 years.
\end{abstract}

Keywords Southern Levant $\cdot$ Sea of Galilee $\cdot$ Pollen analysis $\cdot$ Holocene

\section{Introduction}

The southern Levantine region between the Dead Sea and Mt. Hermon, including the river Jordan catchment area, is an excellent laboratory for the study of Holocene vegetation and climate history in the Near East. Several plant geographical territories converge in this region due to the steep gradient of precipitation (Zohary 1982). Furthermore, the Levant and its surrounding region is the cradle of agriculture and human impact, which extend back about 11,000 years (Bar-Yosef and Belfer-Cohen 1992).

In contrast to the Upper Pleistocene, where the palynological data base is still rather poor, present knowledge of the Holocene vegetation and climate history has been steadily increasing recently. Sedimentological and initial palynological data from Birkat Ram, on the Golan Heights (Schwab et al. 2004) are based on a series of short sediment cores

Communicated by F. Bittmann.

Thomas Litt

t.litt@uni-bonn.de

1 Steinmann Institute of Geology, Mineralogy and Paleontology, University of Bonn, Nussallee 8, 53115 Bonn, Germany obtained in 1999, representing the last ca. 6,500 years. Neumann et al. (2007a) presented the detailed palynology and environmental history, including evidence of human impact for the same time interval. In addition, a new botanical and climatological transfer function has been applied to reconstruct climate variations in the northern Golan Heights area based on this pollen record (Neumann et al. 2007a).

Pollen diagrams are also available from the west shore of the Dead Sea, which allow a reliable reconstruction of the vegetation history of the past 3,500 years (late Holocene); longer Holocene records are discontinuous (Baruch 1990; Heim et al. 1997; Neumann et al. 2007b, 2010; Langgut et al. 2014). A $21 \mathrm{~m}$ sediment core taken from the Dead Sea shore near Ein Gedi provides the most continuous and best dated palynological record of nearly the entire Holocene period in the southern Levant (Litt et al. 2012). The chronology of the core is based on AMS radiocarbon ages of terrestrial organic debris, counts of annual laminae and comparison to historical earthquakes (Migowski et al. 2004, 2006). The results show the natural and human influence on vegetation changes during the Holocene from $\sim 10 \mathrm{ka}$ cal вР to the present. Due to the large catchment size of the Dead Sea drainage basin, the pollen sequence in the sediments is considered to serve as a recorder of the regional palaeoclimate based on biome models (Litt et al. 2012). 
A prominent pollen record is available from Lake Hula in the northern Jordan valley (Baruch and Bottema 1999). It begins, however, in the early Holocene and not during the Late Glacial, as discussed in a revision of the chronology by Van Zeist et al. (2009).

A new pollen record from the southwestern shore of the Sea of Galilee (Lake Kinneret) has been published by Miebach et al. (2017). The core comprises a continuous sediment profile of mainly laminated authigenic calcites (formed in situ) and detrital material that was deposited between ca. 28,000 and 22,500 cal BP, when the Sea of Galilee rose above the modern lake level and temporarily merged with Lake Lisan, the precursor of the Dead Sea. Concerning the Holocene vegetation history of Lake Kinneret, Baruch (1986) analysed a $4 \mathrm{~m}$ sediment core, which covers only the late Holocene, the last 4,000 years. In 2010, a new $17.8 \mathrm{~m}$ long sedimentary core was drilled in the deepest part of Lake Kinneret. Preliminary results have so far been published only for the time interval related to the so-called "Late Bronze Age Collapse" at 3,200 cal вр (Langgut et al. 2013).

In this study, we present the entire palynological sequence obtained from the Kinneret core which covers the last $\sim 9,000$ years. Based on an excellent chronology, special emphasis is given to the natural and human-influenced vegetation history of Galilee related to the regional climate development as shown in the Kinneret lake level record (Hazan et al. 2005). Regarding human impact, we evaluate the start of Olea (olive) cultivation at the Late Neolithic/ Early Chalcolithic transition, as well as the further development of the cultural landscape until the establishment of the present-day Mediterranean vegetation of macchia or bathas scrub, based on the pollen signal in conjunction with the archaeological setting. The comparisons to the more southern Dead Sea records as shown in the well-dated Ein Gedi pollen profile (Litt et al. 2012) as well as to the Holocene lake level curve (Kushnir and Stein 2010; Stein et al. 2010) are also taken into account to show similarities and differences of the vegetation signals related to the steep climatic gradient in the southern Levant.

\section{Area of work}

Lake Kinneret, also known as the Sea of Galilee and Lake Tiberias, is a hard water lake located in the northeast of Israel (Fig. 1). It is a relic of variously sized water bodies which filled the tectonic depressions along the Dead Sea Transform Fault (DST) since the Neogene (Hazan et al. 2005). The modern Lake Kinneret occupies one of
Fig. 1 a Map of Israel and adjacent areas showing relevant cities (circle), rivers, and mountains (triangle); b Lake Kinneret including bathymetric data and the core site (red star) in the middle of the lake

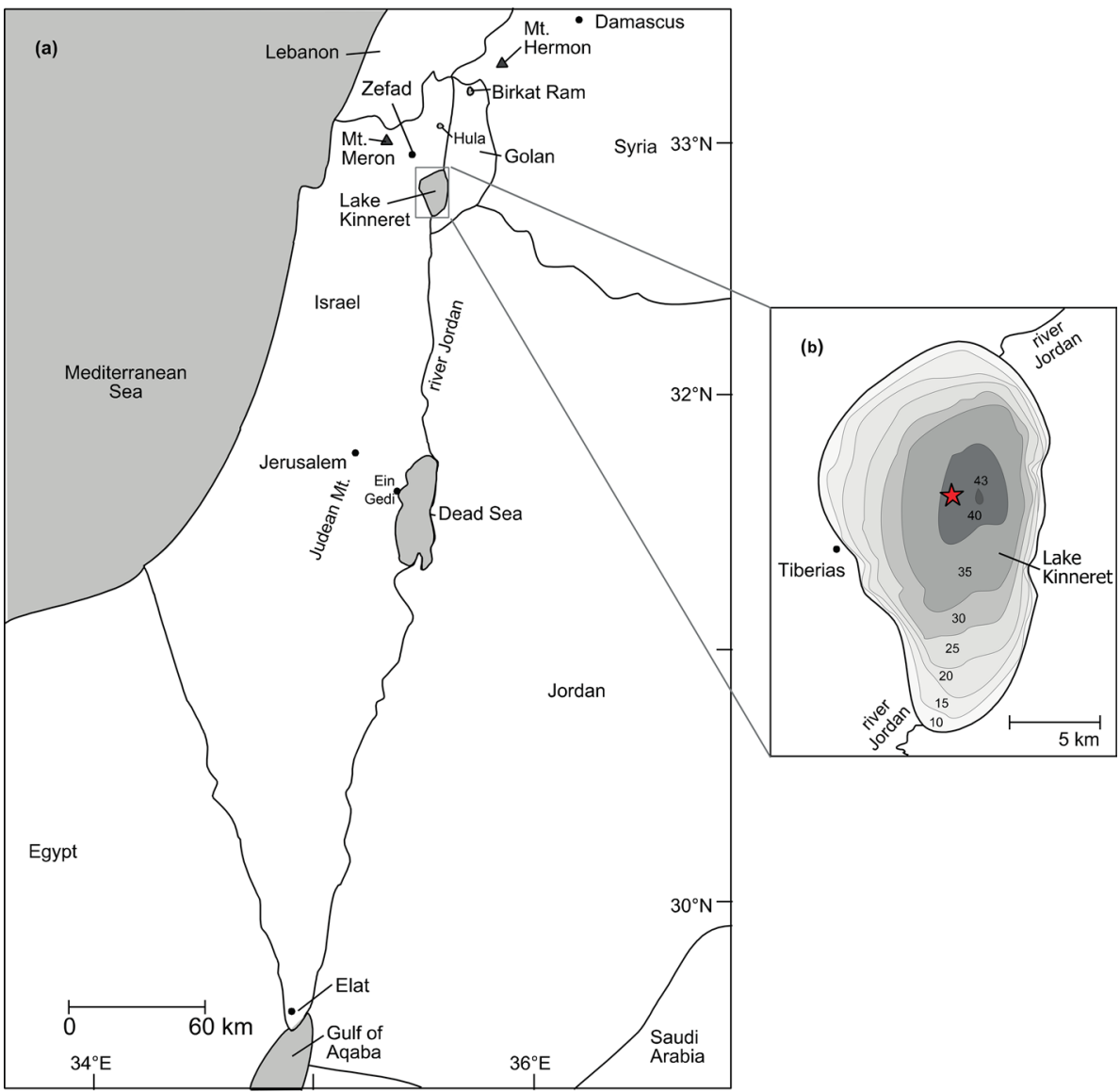


a series of pull-apart basins along the DST. At a lake level of $211 \mathrm{~m}$ b.s.l. (below mean sea level), the central basin is $43 \mathrm{~m}$ deep. The maximum length of the lake is $21 \mathrm{~km}(\mathrm{~N}-\mathrm{S})$ and its maximum width $12 \mathrm{~km}$ (W-E). The surface area of Lake Kinneret is $166 \mathrm{~km}^{2}$ and contains a water body of $4.1 \times 10^{6} \mathrm{~m}^{3}$. It is monomictic lake (that mixes from top to bottom once a year), with a stratification from mid-March to late December (Nishri et al. 1999). The catchment area is $2,760 \mathrm{~m}^{2}$. Most of the inflow, amounting to approximately $477 \times 10^{6} \mathrm{~m}^{3} /$ year, comes from the river Jordan and only small amounts flow in from other streams and seasonal floods (16\%), direct rainfall (9\%) and subaqueous springs $(8 \%)$. The average precipitation over the Kinneret area is $400 \mathrm{~mm}$ per year, and evaporation amounts to $250 \times 10^{6} \mathrm{~m}^{3} /$ year $\pm 10 \%$ (Stiller et al. 1988, 2001). Between 1970 and 1995, the average residence time of water was 5.5 years (Nishri et al. 1999).

The southern Levant can be subdivided into longitudinal topographic patterns which run north to south and which strongly influence the regional climate and therefore vegetation (Zohary 1982; Van Zeist and Bottema 1991). Here, the altitudinal gradient from 1,208 $\mathrm{m}$ a.s.l. (above mean sea level) on mount Meron, Upper Galilee, to the lowest depression of Earth's continental surface level at $-430 \mathrm{~m}$ a.s.l. (Israel Oceanographic and Limnological Research 2017) and the resultant steep slopes cause considerably high sensitivity and variability of the vegetation composition (Fig. 2a, b).

Regional climate conditions have a particularly strong influence on the vegetation distribution. The eastern Mediterranean region includes a transitional climate zone between the North African deserts and the central European West Wind Drift (Boucher 1975). During the summer, the northern position of the North African subtropical high pressure atmospheric system covers the eastern Mediterranean, which results in high temperatures and widespread droughts there (Rohling et al. 2009). The wind system affecting Israel is part of a general westerly air flow, typical of the eastern Mediterranean basin (Levantine

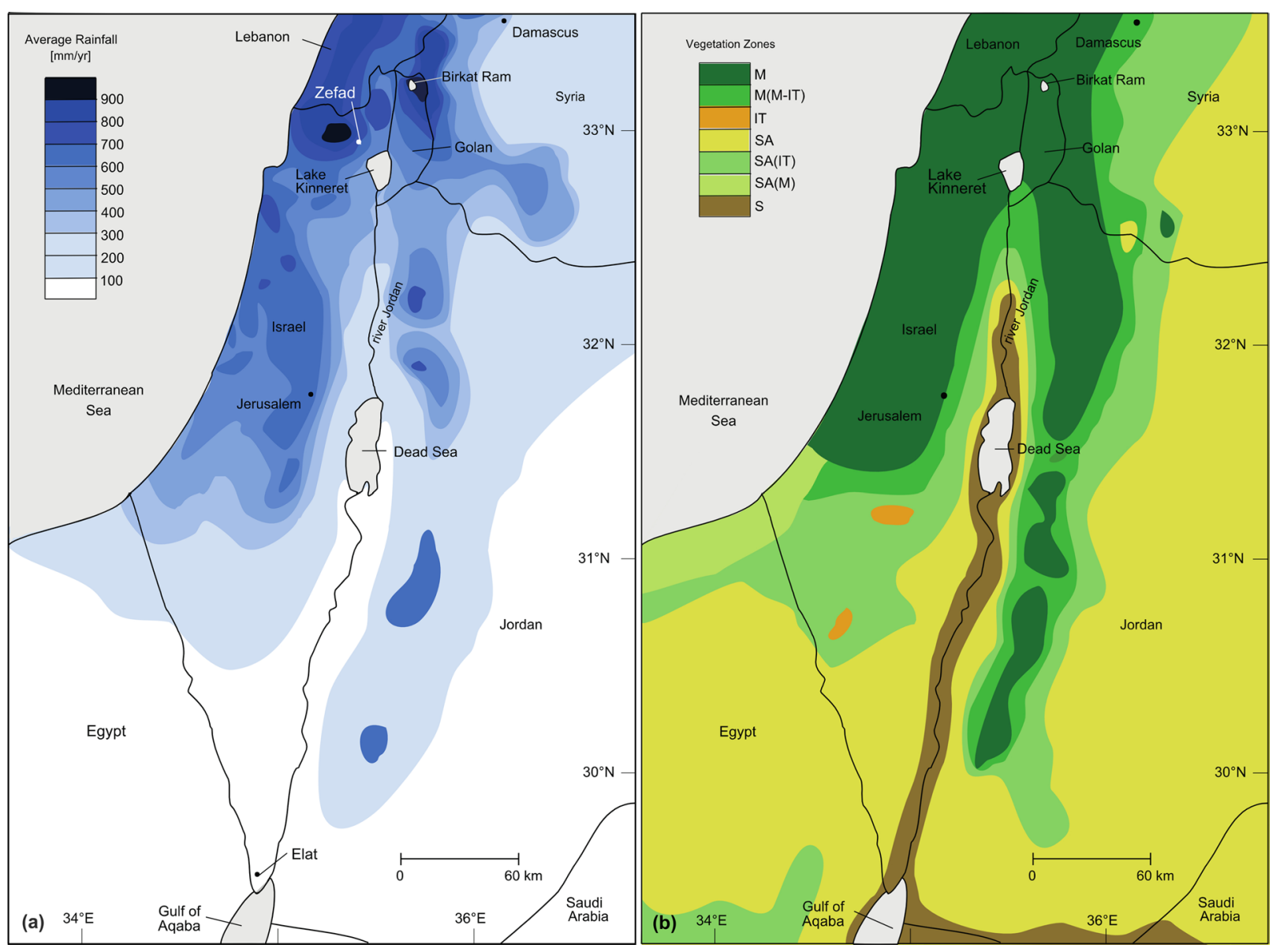

Fig. 2 a Map of Israel and adjacent areas indicating mean annual precipitation in mm/year (after Jaffe 1988); b distribution of vegetation zones in Israel and adjacent areas: MMediterranean zone, IT IranoTuranian zone, SA Saharo-Arabian zone, S Sudano-Zambesian vegetation zone (after Danin 1988). Composite zones such as M (M-IT)

are named after the most frequent zone in combination with the second most frequent one in brackets; $S A(I T)$ transition Saharo-Arabian zone to Irano-Turanian zone, $S A(M)$ transition Saharo-Arabian zone to Mediterranean zone 
basin) during summer. The westerly to north-westerly winds reach the Jordan Rift Valley as hot winds with high speeds $(50 \mathrm{~km} / \mathrm{h}$ on average) and superimpose diurnal elements on the local wind systems (Bitan 1974). Climatic conditions during the winter are less stable, because the subtropical high pressure system is displaced southwards to North Africa, and the eastern Mediterranean is exposed to intensive cyclonic activity (Bitan 1981). The winds crossing the north-south mountain ridges cause intensive winter rainfall over the Levant (Sharon and Kutiel 1986). The rainy season lasts from the end of October to early May and $70 \%$ of the annual precipitation falls between December and February (Karmon 1994). In Israel, latitude, altitude and topographic conditions cause steep gradients in temperature and precipitation. The average annual temperature increases from less than $16{ }^{\circ} \mathrm{C}$ in the north to approximately $23{ }^{\circ} \mathrm{C}$ in the south (Zohary 1962). Within a range of $4^{\circ}$ of latitude, average annual precipitation decreases from more than $1,000 \mathrm{~mm}$ in the northern mountainous regions to approximately $25 \mathrm{~mm}$ in the southernmost part of Israel, the Negev desert (Fig. 2a). Snow fall almost only occurs over the northernmost part of the Golan.

These conditions result in the exceptionally diverse vegetation of Israel. Danin and Plitmann (1987) and Danin (1988) revised previous classifications of the phytogeographical regions (Zohary 1962) and subdivided the flora of Israel into seven vegetation zones with particular environmental requirements (Fig. 2b), two of which are relevant for our area of work:

1. Mediterranean (M) plants, which are distributed around the Mediterranean Sea.

2. Irano-Turanian (IT) plants, which also grow on the Asian steppes of the Syrian desert, in Iran and in Anatolia in eastern Turkey.

The Mediterranean (M) territory, in which average precipitation exceeds $300 \mathrm{~mm}$ per year, is dominated by macchia (maquis) and batha evergreen scrub vegetation (Danin 1988). The main taxa are Quercus ithaburensis and $Q$. boisseri, (deciduous oaks), Q. calliprinos, (evergreen oak), as well as Olea europaea (olive). Further characteristic taxa are Pistacia lentiscus, Arbutus andrachne, Ceratonia siliqua, Pinus halepensis and Sarcopoterium spinosum (Danin 1988; Zohary 1982). Characteristic taxa of the Irano-Turanian (IT) territory, in which average annual precipitation ranges between 300 and $150 \mathrm{~mm}$, are Artemisia herba-alba, Thymelaea hirsuta, Achillea santolina and some Poaceae and Chenopodiaceae (Danin 1988; Zohary 1982). Danin (1988) further subdivides the vegetation zones by adding composite zones in the transitional areas, such as M(M-IT), which are named after the most frequent zone in combination with the second most frequent one in brackets (Fig. 2b).

In general, the composition of the potential natural vegetation depends on climatic factors such as temperature, precipitation, geology and soil. In the southern Levant, precipitation is the main limiting factor for the presence and growth of plants. Human impact has affected the vegetation since the Neolithic (Bar-Yosef 1995; Rollefson and KöhlerRollefson 1992). Therefore, reconstructing the potential natural plant cover is rather complicated.

\section{Materials and methods}

\section{Coring}

The sediment cores were obtained during a drilling campaign in March 2010, as part of the Collaborative Research Centre project CRC 806 "Our Way to Europe", funded by the Deutsche Forschungsgemeinschaft (DFG). For the drilling at the Lake Kinneret core site $\left(32^{\circ} 49^{\prime} 13.8^{\prime \prime} \mathrm{N}, 35^{\circ} 35^{\prime} 19.7^{\prime \prime} \mathrm{E}\right.$, ca $38.8 \mathrm{~m}$ water depth; Fig. 1), we used the Universal Sampling Platform (http://www.uwitec.at) and associated tools produced by UWITEC. The drilling was carried out by using a gravity corer to recover short cores and a piston corer to obtain long cores. Plastic liners with a length of $2 \mathrm{~m}$ and diameters of $90 \mathrm{~mm}$ and/or $60 \mathrm{~mm}$ were used. The sediment cores were taken back to Germany and opened in the pollen laboratory at the University of Bonn. The archive half of each core segment was used for non-destructive analyses such as magnetic susceptibility, and the other half was sampled for pollen analyses.

At the Kinneret core site we obtained two parallel cores, Ki10 I (13.3 m core recovery) and Ki10 II (17.8 m core recovery), which were taken at a distance of $2 \mathrm{~m}$ from each other. From these, a $17.8 \mathrm{~m}$ composite profile was developed (Fig. 3), from which we took pollen samples every $25 \mathrm{~cm}$. A detailed sedimentological description of the sediment cores was done, which showed that the upper $25 \mathrm{~cm}$ was varved. The varves are assumed to have formed after the damming of the natural outflow by the National Water Carrier in 1964 (Ami Nishri, personal communication). Below the varved section, the sediment cores consisted of homogenous greyish to brown silts and clays. No major changes in appearance, colour or texture were found.

\section{Magnetic susceptibility}

The high resolution magnetic susceptibility data set produced at the Institute of Geology and Mineralogy at the University of Cologne was used for the correlation of the parallel cores and for the definition of the Lake Kinneret composite profile (Fig. 3). Measurements on the 


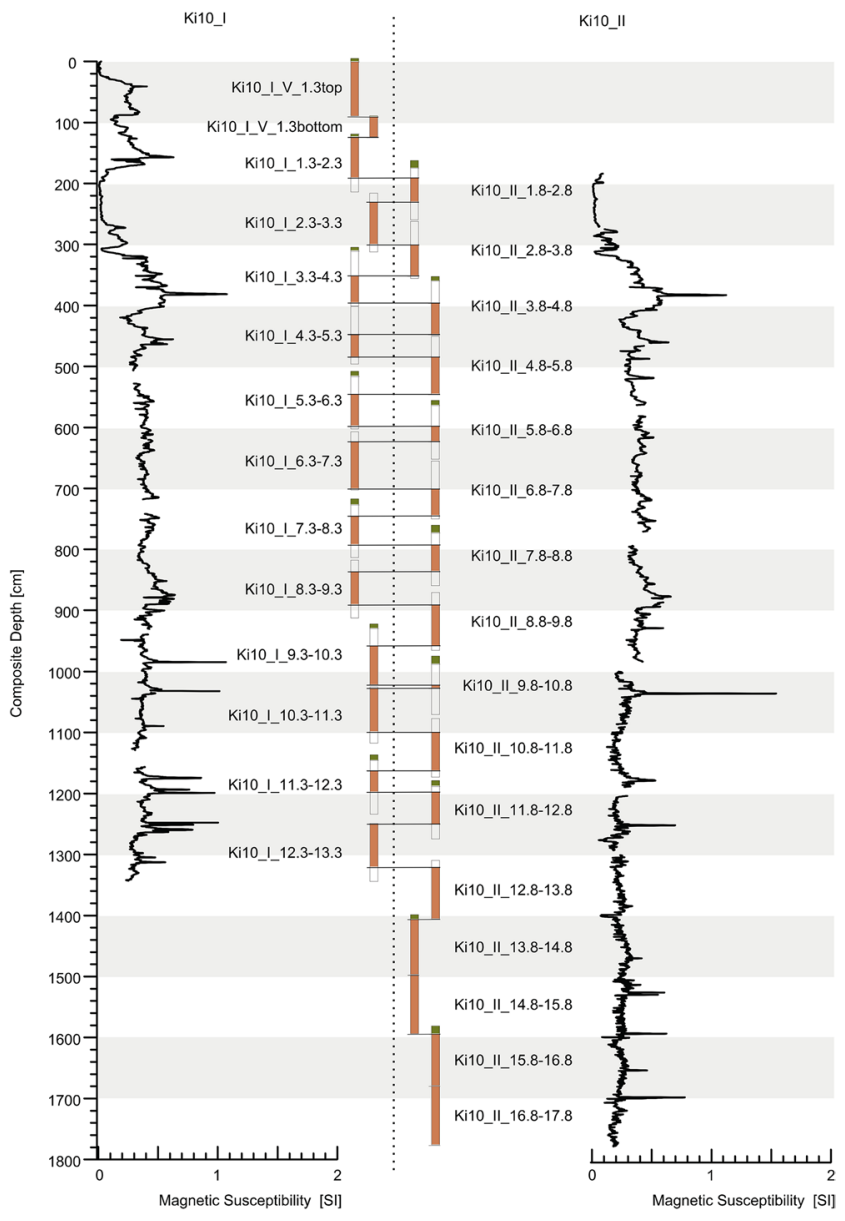

Fig. 3 Construction of the Lake Kinneret composite profile. The two parallel cores (Ki10 1 and Ki10 II) were correlated based on magnetic susceptibility (SI, black line). The beige-coloured sections constitute the composite profile; the green-coloured sections mark the core filling compounds

longitudinally split core surfaces were carried out using a spot-reading Bartington MS2E sensor. The response area of the sensor was $3.8 \times 10.5 \mathrm{~mm}$, and the operating frequency $2 \mathrm{kHz}$. At a vertical depth of $1 \mathrm{~mm}$, the response is reduced by approximately $50 \%$, and the reduction at a depth of $3.5 \mathrm{~mm}$ is approximately $90 \%$. Data were measured at $1 \mathrm{~mm}$ intervals with a period of $15 \mathrm{~s}$.

\section{Pollen analyses}

Sediment cores were sampled for pollen analyses at $25 \mathrm{~cm}$ intervals. Average sample volume was approximately $5 \mathrm{~cm}^{3}$. Chemical treatment followed the standard procedure according to Faegri and Iversen (1989), including application of $10 \% \mathrm{HCl}, 10 \% \mathrm{KOH}, 40 \% \mathrm{HF}$ and acetolysis $\left[\mathrm{C}_{4} \mathrm{H}_{6} \mathrm{O}_{3}\right.$ (conc.) and $\mathrm{H}_{2} \mathrm{SO}_{4}$ (conc.), ratio 9:1]. Ultrasonic sieving was carried out twice during the procedure using 200 and $10 \mu \mathrm{m}$ meshes. The samples were stained with safranin and stored in glycerol. At least 500 pollen grains per sample were counted using transmitted light microscopy with a Leica DME and a Zeiss Lab.A1 AX10, at 400× magnification. Pollen grains were identified to the highest possible systematic level. The extensive comparative collection of palynomorphs available at the Department of Paleobotany and Palynology at the Steinmann Institute, University of Bonn, was used as reference for identification. In addition, various textbooks of circum-Mediterranean pollen grains were used (Reille 1992; Moore et al. 1991; Beug 2004). Pollen diagrams were plotted with Tilia 1.7.14 by Eric (Grimm 2011, Illinois State Museum, Springfield). The definitions of the lower boundaries of local pollen assemblage zones (LPAZs) were defined visually and then verified by cluster analysis using thresholds (CONISS) (Grimm 1987).

\section{Radiocarbon dating}

Ten macrofossil remains of terrestrial plants and 21 samples of bulk organic material were AMS radiocarbon dated, mainly in Kiel, with additional datings done in Zürich and London (Table 1). Pre-treatment of plant macrofossils included dispersion of samples in de-ionized water and elimination of mechanical contaminants such as associated sediments. Subsequently, hot $\mathrm{HCl}$ was used to remove carbonates and $\mathrm{NaOH}$ to remove secondary organic acids. Bulk sample sediments were also dispersed in de-ionized water and repeatedly treated with $\mathrm{HCl}$ at $60{ }^{\circ} \mathrm{C}$ to remove carbonates. The remaining carbon in each sample was burned at $900{ }^{\circ} \mathrm{C}$ in a quartz ampoule filled with copper oxide $(\mathrm{CuO})$ and silver wool. The resulting $\mathrm{CO}_{2}$ was reduced to graphite at $600{ }^{\circ} \mathrm{C}$, and counted by AMS. The AMS results, which are ratios of ${ }^{14} \mathrm{C},{ }^{13} \mathrm{C}$ and ${ }^{12} \mathrm{C}$, were compared to an oxalic acid standard. The received data were corrected for isotopic fractionation using the simultaneously measured ${ }^{13} \mathrm{C} /{ }^{12} \mathrm{C}$ ratio, which includes effects occurring during graphitisation and within AMS processes. All ${ }^{14} \mathrm{C}$ ages were calculated after Stuiver and Polach (1977) and calibrated by the 'clam' software based on the IntCal09 calibration curve (Blaauw 2010; Reimer et al. 2009). Data were computed at a $95 \%$ confidence interval $(2 \sigma)$, and intermediate values were established by linear interpolation between dated levels of the age-depth curve (Fig. 4).

\section{Results}

\section{Chronology}

The occurrence of Eucalyptus pollen in the uppermost sample proves the recent age of the sediment to water interface of the Kinneret core. A neophyte in the Near East, Eucalyptus is native to Australia and was introduced to the area by 
Table 1 Radiocarbon dates using Accelerator Mass Spectrometry (AMS) from Lake Kinneret

\begin{tabular}{|c|c|c|c|c|}
\hline Lab. & Lab. code & Depth $(\mathrm{cm})$ & Age $\left({ }^{14} \mathrm{C}\right.$ yrs вP $)$ & Material \\
\hline Kiel & KIA48027 & 4.5 & $880 \pm 30$ & $\begin{array}{l}\text { Bulk, humic } \\
\text { acid }\end{array}$ \\
\hline \multirow[t]{2}{*}{ Kiel } & \multirow[t]{2}{*}{ KIA48028 } & \multirow[t]{2}{*}{98.5} & $1,470 \pm 30$ & Bulk sediment \\
\hline & & & $1,480 \pm 35$ & Humic acid \\
\hline \multirow[t]{2}{*}{ Kiel } & \multirow[t]{2}{*}{ KIA48029 } & \multirow[t]{2}{*}{199.5} & $2,175 \pm 30$ & Bulk sediment \\
\hline & & & $2,190 \pm 40$ & Humic acid \\
\hline \multirow[t]{2}{*}{ Kiel } & \multirow[t]{2}{*}{ KIA48030 } & \multirow[t]{2}{*}{304.5} & $2,670 \pm 25$ & Bulk sediment \\
\hline & & & $2,870 \pm 25$ & Humic acid \\
\hline London & Beta-327805 & 357.5 & $2,990 \pm 30$ & $\begin{array}{l}\text { Total bulk sedi- } \\
\text { ment }\end{array}$ \\
\hline Kiel & KIA44213 & 359.5 & $2,155 \pm 25$ & Plant remains \\
\hline \multirow[t]{2}{*}{ Kiel } & \multirow[t]{2}{*}{ KIA48031 } & \multirow[t]{2}{*}{394.5} & $3,275 \pm 30$ & Bulk sediment \\
\hline & & & $3,315 \pm 30$ & Humic acid \\
\hline Zurich & ETH48430 & 397.05 & $2,123 \pm 38$ & Plant remains \\
\hline \multirow[t]{2}{*}{ Kiel } & \multirow[t]{2}{*}{ KIA48032 } & \multirow[t]{2}{*}{494.5} & $3,545 \pm 30$ & Bulk sediment \\
\hline & & & $3,615 \pm 25$ & Humic acid \\
\hline Kiel & KIA48033 & 605.5 & $4,515 \pm 35$ & $\begin{array}{l}\text { Bulk, humic } \\
\text { acid }\end{array}$ \\
\hline Kiel & KIA48034 & 705.5 & $4,910 \pm 30$ & $\begin{array}{l}\text { Bulk, humic } \\
\text { acid }\end{array}$ \\
\hline Zurich & ETH48434 & 752.0 & $3,474 \pm 104$ & Plant remains \\
\hline \multirow[t]{3}{*}{ Kiel } & \multirow[t]{3}{*}{ KIA48035 } & \multirow[t]{3}{*}{793.5} & $3,800 \pm 45$ & Plant remains \\
\hline & & & $4,765 \pm 30$ & Bulk sediment \\
\hline & & & $4,795 \pm 30$ & Humic acid \\
\hline Zurich & ETH48433 & 798.5 & $3,832 \pm 32$ & Plant remains \\
\hline Kiel & KIA48036 & 890.5 & $5,740 \pm 40$ & $\begin{array}{l}\text { Bulk, humic } \\
\text { acid }\end{array}$ \\
\hline Zürich & ETH48429 & 901.0 & $4,086 \pm 42$ & Plant remains \\
\hline London & Beta-336208 & 921.0 & $4,230 \pm 30$ & Plant remains \\
\hline London & Beta-327806 & 943.5 & $5,800 \pm 40$ & $\begin{array}{l}\text { Total bulk sedi- } \\
\text { ment }\end{array}$ \\
\hline Kiel & KIA44214 & 945.0 & $4,165 \pm 40$ & Plant remains \\
\hline Kiel & KIA44215 & 946.5 & $4,100 \pm 25$ & Plant remains \\
\hline \multirow[t]{2}{*}{ Kiel } & \multirow[t]{2}{*}{ KIA48037 } & \multirow[t]{2}{*}{992.5} & $5,900 \pm 40$ & Bulk sediment \\
\hline & & & $5,900 \pm 35$ & Humic acid \\
\hline Kiel & KIA44216 & 993.5 & $5,870 \pm 60$ & Plant remains \\
\hline \multirow[t]{2}{*}{ Kiel } & \multirow[t]{2}{*}{ KIA48038 } & \multirow[t]{2}{*}{$1,093.5$} & $6,655 \pm 45$ & Bulk sediment \\
\hline & & & $7,145 \pm 45$ & Humic acid \\
\hline \multirow[t]{2}{*}{ Kiel } & KIA48039 & $1,181.5$ & $7,145 \pm 50$ & Bulk sediment \\
\hline & & & $7,140 \pm 40$ & Humic acid \\
\hline Kiel & KIA48040 & $1,277.5$ & $7,675 \pm 40$ & $\begin{array}{l}\text { Bulk, humic } \\
\text { acid }\end{array}$ \\
\hline Kiel & KIA48041 & $1,378.5$ & $7,700 \pm 40$ & Bulk sediment \\
\hline & & & $7,705 \pm 40$ & Humic acid \\
\hline Kiel & KIA48042 & $1,472.5$ & $8,480 \pm 45$ & Bulk sediment \\
\hline & & & $8,540 \pm 45$ & Humic acid \\
\hline Kiel & KIA48043 & $1,572.5$ & $8,860 \pm 45$ & Bulk sediment \\
\hline & & & $8,910 \pm 45$ & Humic acid \\
\hline Kiel & KIA48045 & $1,777.5$ & $9,805 \pm 45$ & Bulk sediment \\
\hline & & & $9,855 \pm 45$ & Humic acid \\
\hline
\end{tabular}

Shown are the sample identifier (Lab ID), the composite depth in $\mathrm{cm}$, the ${ }^{14} \mathrm{C}$ ages in $\mathrm{BP}$, the investigating lab and the type of analysed material. Some samples were dated twice

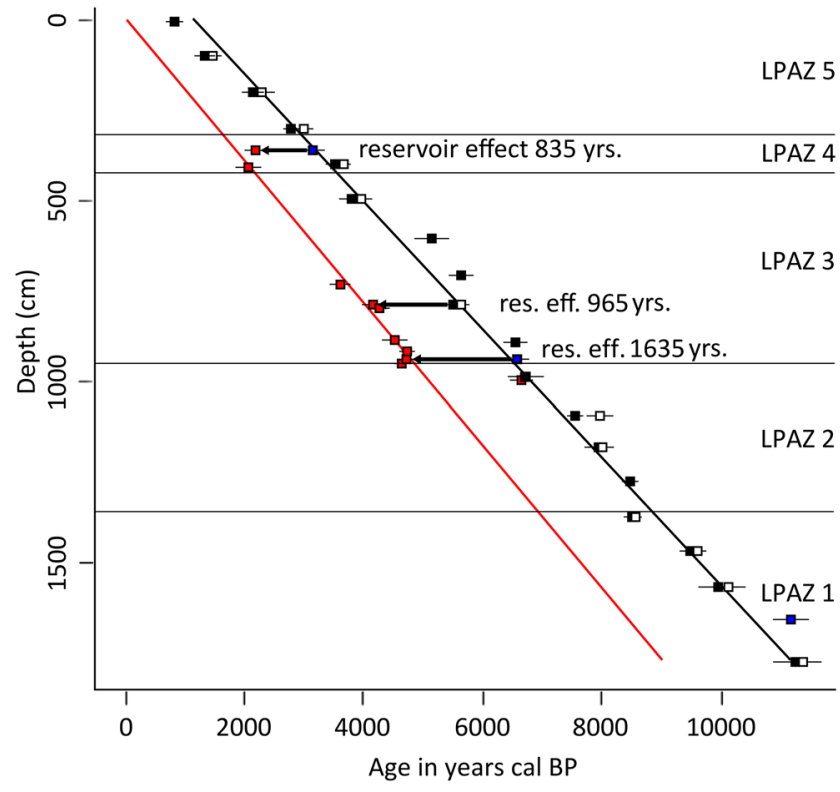

Fig. 4 Age-depth model of the Lake Kinneret composite profile based on calibrated radiocarbon dates. Shown are the dates from terrestrial plant remains are shown as red squares, from total bulk organic material as blue squares and from the humic acid fraction based dates from bulk organic material (partly two measurements each sample; black and white squares). Error bars indicate $2 \sigma$ range. The black arrows display the reservoir correction at the depth horizons 358, 794 and $944 \mathrm{~cm}$ with both plant macrofossil and bulk organic samples

the end of the 19th century. It was planted by Jewish settlers to drain swampy land in northern Israel at the beginning of the 20th century, and since that time it has been a component of the modern pollen rain (Horowitz 1979). For dating the rest of the core, we could only analyse ten usable plant macrofossil remains of terrestrial origin. For the other dates, bulk organic material was used for AMS dating (Table 1). As the age-depth distribution of dates from the bulk samples is clearly linear (Fig. 4), an almost stable sedimentation rate can be assumed. From a sedimentological point of view, this assumption is supported by the homogenous nature of the deposited sediments. Consequently, the age-depth distribution of terrestrial macrofossil remains, including the recent age of the sediment to water interface, can also be assumed to be linear.

Radiocarbon ages from both plant remains and from bulk sediments from the same sample could be measured at three depth horizons, at 358, 794 and $944 \mathrm{~cm}$. This allowed us to estimate the reservoir correction based on the difference between the dates of plant remains and bulk sediment samples. Thus, the magnitude of the reservoir effect at $358 \mathrm{~cm}$ is 835 years, at $794 \mathrm{~cm}$ it is 965 years, and at $944 \mathrm{~cm}$ 1,635 years (Fig. 4). Although reservoir effects are in general highly variable through time (Geyh et al. 1998), the resulting regression lines of both data sets based on bulk sediments and terrestrial plant macrofossils point to a slightly 
Fig. 5 The complete pollen diagram of Lake Kinneret. The local pollen assemblage zones (LPAZs) are shown on the right

but constantly greater reservoir correction at increasing depth (Fig. 4). Assumptions concerning the magnitude of the reservoir effects of the Lake Kinneret water and deposited sediments diverge to some degree (Stiller et al. 2001; Lev et al. 2007). However, neither the evolution of lake level nor carbonate source system are entirely understood so far (Hazan 2004; Hazan et al. 2005).

Assuming a linear age-depth distribution of dates and an increasing reservoir effect, an age-depth model was developed, resulting in the linear regression line: y $($ depth $)=0.1967 \times($ age $)$. This reservoir correction model has also been used for the lower part of the sediment profile where no radiocarbon data from terrestrial macrofossils are available. Based on these calculations, the whole sequence covers the last ca. 9,000 cal years (Fig. 4).

\section{Pollen analysis}

Percentages of pollen types have been calculated according to total terrestrial pollen sums, which include arboreal (AP) and non-arboreal (NAP) pollen taxa, excluding aquatic taxa as well as unidentified pollen grains. The pollen record can be subdivided into five palynostratigraphic units, or local pollen assemblage zones (LPAZs) (Fig. 5; Table 2). These LPAZs are distinguished either by the specific composition of taxa ("assemblage zone") or by significant changes of frequency of particular taxa ("abundance zone") (Murphy and Salvador 1999; Steininger and Piller 1999). The zonation of the Lake Kinneret pollen record is mainly based on pollen percentages of O. europaea, Q. ithaburensis-type, Q. calliprinos-type and the AP/NAP ratio. Descriptions of the pollen assemblage zones as well as the criteria used for defining the lower boundaries are given in Table 2 .

\section{Discussion}

\section{9,000-7,000 cal BP (Pottery Neolithic period)}

The predominance of Poaceae, Chenopodiaceae and Cichorioideae pollen indicates the strong influence of steppe vegetation in the catchment area. This vegetation zone can be assumed to have stretched around the shore of Lake Kinneret and to have been part of the understorey of the open woodlands on the slopes of the mountain ranges within the IranoTuranian biome. As well as being part of the regional vegetation, pollen grains of steppe taxa could have been brought in via long distance transport from Syrian steppe regions (Baruch 1986). The source area of $Q$. ithaburensis-type pollen in the Lake Kinneret record would have been on the

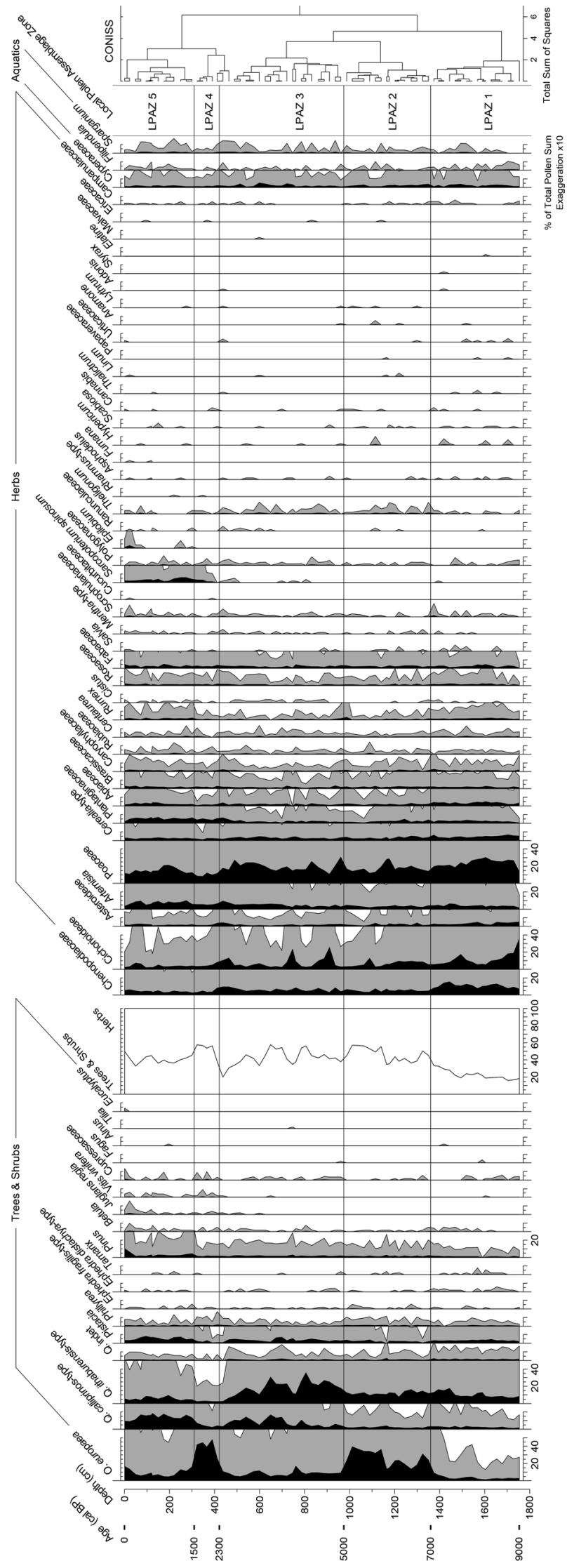


Table 2 Description of the local pollen assemblage zones (LPAZs) in the Lake Kinneret record ( $A P$ arboreal pollen, $N A P$ non-arboreal pollen; see also Fig. 5)

\begin{tabular}{|c|c|c|c|c|}
\hline $\begin{array}{l}\text { Local Pollen Assemblage } \\
\text { Zone (LPAZ) }\end{array}$ & Depth $(\mathrm{cm})$ & Lower boundary & Features AP (min. to max.) & Features NAP (min. to max.) \\
\hline $\begin{array}{l}5 \text { Quercus calliprinos- } \\
\text { type-Pistacia LPAZ }\end{array}$ & $0-311.5$ & $\begin{array}{l}\text { Q. calliprinos- } \\
\text { type }>10 \%\end{array}$ & $\begin{array}{l}\text { AP (33-50\%); predominance of } Q \text {. } \\
\text { calliprinos-type (9-18\%); distinct } \\
\text { decline of Olea europaea percentages } \\
\text { at the beginning of this zone (4-17\%); } \\
\text { Q. ithaburensis-type and Pistacia } \\
\text { pollen consistently range around 7\%; } \\
\text { remarkable values of Pinus (1-10\%); } \\
\text { occurrence of Eucalyptus as neophyte } \\
\text { in uppermost part }\end{array}$ & $\begin{array}{l}\text { NAP (50-67\%); increasing } \\
\text { Poaceae values between } 195 \text { and } \\
175 \mathrm{~cm}(11-21 \%) ; \text { remarkable } \\
\text { amounts of Artemisia }(3-10 \%), \\
\text { Plantaginaceae }(2-7 \%), \text { Sar- } \\
\text { copoterium spinosum (1-6\%), } \\
\text { and Rumex (1-2\%); Chenopodi- } \\
\text { aceae, Cichorioideae, and Aster- } \\
\text { oideae fluctuate at low level }\end{array}$ \\
\hline $\begin{array}{l}4 \text { Olea europaea-Sarco- } \\
\text { poterium spinosum LPAZ }\end{array}$ & $311.5-428$ & O. europaea $>20 \%$ & $\begin{array}{l}\text { AP }(38-58 \%) \text {; highest values of } O \text {. } \\
\text { europaea }(26-48 \%) \text {, decreasing } \\
\text { percentages of } Q . \text { calliprinos-type } \\
(2-7 \%), Q \text {. ithaburensis-type }(2-3 \%), \\
\text { and Pistacia }(1-3 \%) \text {; start of con- } \\
\text { tinuous occurrence of Vitis vinifera } \\
(0-1 \%) \text { and Juglans regia }(0-1 \%)\end{array}$ & $\begin{array}{l}\text { NAP (42-62\%); percentages of } \\
\text { Poaceae (8-12\%), Chenopodi- } \\
\text { aceae and Cichorioideae (both at } \\
3-8 \%) \text { decline; increasing values } \\
\text { of Plantaginaceae (4-6\%); start } \\
\text { of continuous occurrence of } S \text {. } \\
\text { spinosum }(0-3 \%)\end{array}$ \\
\hline $\begin{array}{l}\text { 3 Q. ithaburensis-type } \\
\text { LPAZ }\end{array}$ & $428-976.5$ & $\begin{array}{l}\text { Q. ithaburensis- } \\
\text { type }>15 \%\end{array}$ & $\begin{array}{l}\text { AP (20-58\%); highest values of } Q \text {. } \\
\text { ithaburensis-type }(2-36 \%) \text {; } Q \text {. } \\
\text { calliprinos-type }(2-17 \%) \text { percentages } \\
\text { increase, general low } O \text {. europaea } \\
\text { (5-17\%) values with two distinct } \\
\text { peaks at } 761 \mathrm{~cm}(17 \%) \text { and at } 599 \mathrm{~cm} \\
\text { (12\%), Pistacia pollen oscillates at } \\
\text { low level (1-7\%) }\end{array}$ & $\begin{array}{l}\text { NAP }(42-80 \%) \text {; predominance of } \\
\text { Poaceae }(11-31 \%) \text {; three distinct } \\
\text { peaks of Cichorioideae values at } \\
911 \mathrm{~cm}(25 \%) \text {, at } 747 \mathrm{~cm}(23 \%) \\
\text { and at } 464 \mathrm{~cm}(13 \%) \text {; Cheno- } \\
\text { podiaceae (3-9\%), Artemisia } \\
(2-9 \%) \text { and Asteroideae (1-4\%) } \\
\text { are abundant }\end{array}$ \\
\hline 2 O. europaea LPAZ & $976.5-1,365$ & O. europaea $>15 \%$ & $\begin{array}{l}\text { AP }(35-57 \%) \text {; predominance of } O \text {. } \\
\text { europaea }(13-39 \%) \text { with three distinct } \\
\text { peaks at } 1,325 \mathrm{~cm}(31 \%) \text {, at } 1,219 \mathrm{~cm} \\
(24 \%) \text {, and between } 1,140 \text { and } \\
1,012 \mathrm{~cm}(32-39 \%) ; Q . \text { ithaburensis- } \\
\text { type }(8-16 \%) \text { remains stable, while } Q . \\
\text { calliprinos-type (1-4\%) and Pistacia } \\
(0-4 \%) \text { abundances decline }\end{array}$ & $\begin{array}{l}\text { NAP (43-65\%); Poaceae pollen } \\
\text { are continuously present at high } \\
\text { level }(12-29 \%) \text {; Cichorioideae } \\
(3-13 \%), \text { Chenopodiaceae } \\
(3-7 \%), \text { Asteroideae }(1-4 \%) \\
\text { percentages are reduced; Artemi- } \\
\text { sia } \text { still fluctuates at a low level } \\
(2-5 \%)\end{array}$ \\
\hline $\begin{array}{l}1 \text { Poaceae-Cerealia-type } \\
\text { LPAZ }\end{array}$ & $1,365-1,780$ & Not defined & $\begin{array}{l}\text { AP (16-33\%); moderate } Q \text {. ithaburen- } \\
\text { sis-type (7-17\%) and } O \text {. europaea } \\
\text { (1-9\%) values increase towards the } \\
\text { top; low values of Pistacia }(2-4 \%) \text { and } \\
Q . \text { calliprinos-type }(1-3 \%)\end{array}$ & $\begin{array}{l}\text { NAP }(67-80 \%) \text {; remarkable } \\
\text { amounts of Poaceae }(13-30 \%) \text {, } \\
\text { Chenopodiaceae (7-15\%) and } \\
\text { Cichorioideae (5-36\%) in upper } \\
\text { half; Cerealia-type (3-7\%), Arte- } \\
\text { misia (2-6\%) and Asteroideae } \\
\text { (2-5\%) fluctuate at low level }\end{array}$ \\
\hline
\end{tabular}

The pollen zones are plotted against composite depth $\mathrm{cm}$; see also Fig. 4 for the age-depth model

eastern slopes of Lower Galilee, the upper Jordan valley, and the southern Golan Heights (Baruch 1986), which belong to the Mediterranean plant territory (Danin 1988). The Pistacia pollen in the Levantine records originates largely from $P$. palaestina, which is the only species which is reasonably well represented in the pollen rain, since $P$. atlantica and P. lentiscus are seriously underrepresented (Baruch 1986).

Ratios of Mediterranean trees and shrubs in the Lake Kinneret region reach rather low values during LPAZ 1. Referring solely to the pollen record, it cannot be concluded whether this pattern is caused by woodland clearance by the Neolithic people, as assumed by Rollefson and Köhler-Rollefson (1992), or rather by an expansion of the Irano-Turanian steppe biome due to increasing aridity. Although Cerealia-type pollen can be identified from other grasses, it is impossible to distinguish between domesticated and wild cereals. Wild cereals are native in the whole Levant as part of the so-called Fertile Crescent. In this situation, the cereal pollen curve cannot be used as an indicator of human activity in this region (see also van Zeist et al. 2009 and; Litt et al. 2012 for a comparable period in the Hula and Dead Sea pollen records).

Archaeological findings reveal no evidence for largescale woodland clearance activity during the Pottery Neolithic (PN) but rather conclude low settlement density in the southern Levant (Ahlström and Rollefson 1993). Moreover, 
the reconstruction of the level of the Dead Sea shows a low water level between 9,000 and 7,000 cal BP, indicating a period of increased aridity (Kushnir and Stein 2010; Litt et al. 2012), which is consistent with a dry phase deduced by Rohling and Palike (2005). Therefore, an increase in aridity can be assumed as a major reason for the observed vegetation signal in the Kinneret pollen record. A contradictory conclusion is drawn by Yasuda et al. (2000), who noted a sharp decrease in deciduous oak around 9,000 вр in a pollen record from Ghab valley, Syria, as the earliest evidence for large-scale woodland clearance. However, no correction for reservoir effects was applied to the measured radiocarbon ages obtained from these sediments. Instead, Yasuda et al. (2000) refer to the good correlation with the chronology of the Lake Hula profile (Baruch and Bottema 1999), which has since been rejected (van Zeist et al. 2009). Adopting the suggested biostratigraphical correlation with an adjacent profile from Ghab valley by Rossignol-Strick (1995), the age discrepancy might well add up to $\sim 3,500$ years, and hence the evidence for woodland clearance during the Pottery Neolithic has to be questioned.

\section{7,000-5,000 cal BP (transition Neolithic/Chalcolithic to Early Bronze Age)}

The increase of $O$. europaea pollen values with a first peak around $6,800 \mathrm{cal}$ вP is obvious in the bottom part of LPAZ 2 in the Kinneret record (Fig. 6). Such large amounts of olive pollen might be the earliest observable evidence for olive growing as well as clear evidence of human impact on the vegetation in this region. A similar pattern in the olive curve can be observed in the Dead Sea pollen record, starting during the Late Chalcolithic Ghassulian culture (the terminology follows Garfinkel et al. 2014) around 6,500 cal вр (4550 BCE) based on a reliable chronology (Fig. 7; Litt et al. 2012). In the Lake Hula pollen record, the olive curve pattern is similar to those of the previously mentioned records. The different date of the start of the Olea curve in Lake Hula may be due to inaccuracies of the estimated chronology after van Zeist et al. (2009).

Based on the age-depth models of the Kinneret and Dead Sea pollen records, the beginning of olive growing in the Galilee area seems to have been several 100 years earlier than in the Judean mountains around the Dead Sea. This might be related to uncertainties of the reservoir correction used for the Kinneret radiocarbon chronology. However, it is interesting to note that the domesticated status of olives is already shown by archaeobotanical finds from the classical Late Chalcolithic site Tuleilat Ghassul (ca. 6,500-5,800 cal BP) north of the Dead Sea (Neef 1990; Weiss 2015), which is outside the potential natural distribution area of wild Olea as a component of the Mediterranean biome (Danin 1988, 1999). Considerable olive oil production took place as early as the pre-Gassulian late Pottery Neolithic/Early

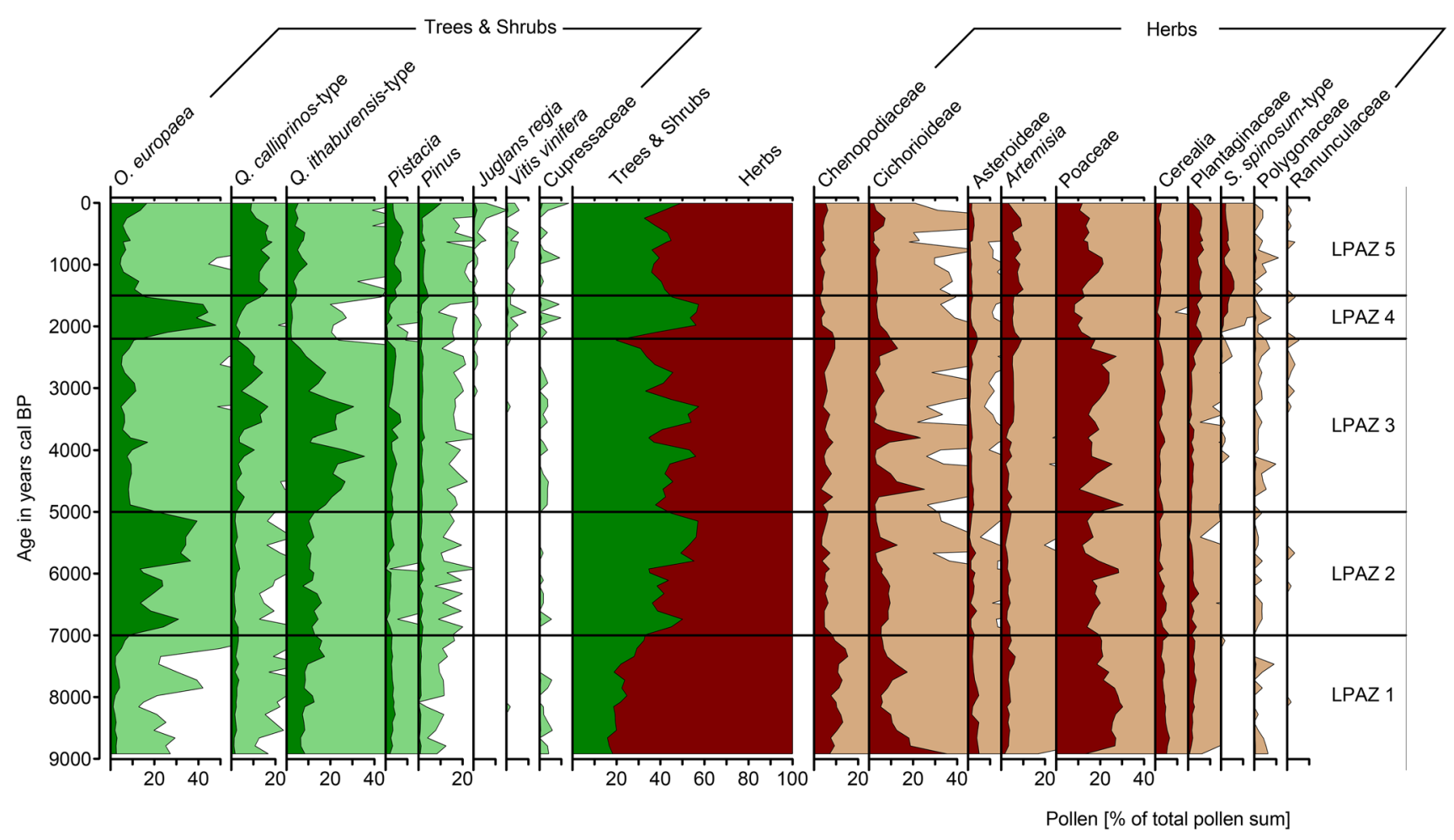

Fig. 6 Selected arboreal pollen and non-arboreal pollen diagram from Lake Kinneret based on an absolute time scale 
Chalcolithic along the Carmel coast and Lower Galilee, probably using wild Olea oleaster forms as described by Kislev (1994-1995), Galili et al. (1997) and summarized in reviews by Kaniewski et al. (2012) and Weiss (2015). Furthermore, very recent evidence of olive oil in pottery containers from Ein Zipporat, southwest of the Sea of Galilee and dating to the 6th and 5th millennia BCE show that the beginning of oil production was several centuries earlier (Namdar et al. 2015). The analytical results based on gas chromatography show that at least the storage of olive oil was a routine custom of the pre-Gassulian culture during the Late Neolithic/Early Chalcolithic. Therefore, we can assume an even earlier growing or use of olives in the Mediterranean region of the Levant where wild olives are native. Although pollen morphology alone is unable to distinguish between wild $O$. oleaster and domesticated $O$. europaea forms, an increased use of olive should be visible in the pollen records from areas such as Lower Galilee where growing probably also took place. In this respect, the first peak of the Olea curve in the Kinneret record around 6,800 BP is in agreement with the previously described findings and assumptions. That Lower Galilee was in fact a hotspot of olive cultivation can also be confirmed by recently published pollen data from the northern Levant, where Olea pollen is absent or only present at very low values during the Late Neolithic/ Chalcolithic period (Hajar et al. 2008, 2010). Therefore, it is not possible with those records to know whether or not olives were cultivated in Lebanon during that time, as stated by Hajar et al. (2010).

The climatic conditions in the Kinneret area seem to have changed to higher precipitation values after 7,000 cal BP (5050 BCE), enabling an expansion of the Mediterranean vegetation. The same tendency can be observed in the Ein Gedi pollen record (Fig. 7; Litt et al. 2012). In addition, a rise in the level of the Dead Sea is also indicative of more rainfall during this period (Kushnir and Stein 2010). The fluctuations in the Olea percentages in the Kinneret record during the Late Chalcolithic period (Gassulian period, ca. 6,500-5,800 cal BP) clearly reflect changes in the amount of human activity rather than changes in the climatic conditions, since the ratios of Mediterranean taxa such as deciduous oak remain constant. High values of Olea pollen can also be observed during the Early Bronze Age I (ca. $5,500 \mathrm{cal} \mathrm{BP}$ ), which is in good agreement with pronounced settlement activities near Kinneret, as at the 20 ha Tel Bet Yerah site (Zwickel 2003), on the Golan Heights (Neumann et al. 2007a), in northern Samaria, and the western Jezreel valley (Finkelstein et al. 2006).

\section{5,000-2,300 cal Bp (Early Bronze to Iron Age)}

The ending of olive growing around 5,000 cal BP (transition from LPAZ 2 to LPAZ 3) occurred synchronously with an increase in deciduous oak pollen (Q. ithaburensis-type). Apparently, the decline of olive cultivation was not related to changes in climatic conditions such as reduced precipitation. This assumption is supported by evidence of a high lake level at Kinneret (Hazan et al. 2005) as well as at the Dead Sea, which suggest that there were higher precipitation values around 5,000 cal BP (Kushnir and Stein 2010; Litt et al. 2012). The decline of olive pollen values was probably linked to changes in socio-economic and political conditions in the region during the Early Bronze Age II and III as discussed in Langgut et al. (2013), according to which a weakening of overland connections with Egypt led to a change in the olive oil export area from Galilee to the coast of present-day Lebanon. Relatively low olive pollen values are also characteristic of the Middle and Late Bronze Age (4,000-3,300 cal вP). In contrast to other regions in the southern Levant, it is interesting that no large city-like settlement structures were established close to the lake during the Middle Bronze Age (Zwickel 2003). The abandonment of the olive groves indicated in the Kinneret record is consistent with the results by Neumann et al. (2007a) based on the Birkat Ram record, which also show reduced human activities on the Golan Heights after the Early Bronze Age. Also, the chronologically well-dated Dead Sea pollen record as well as archaeological and archaeobotanical findings indicate a decline of olive cultivation along with a decrease of settlement density and economic activities in southern Israel by the Late Bronze Age (3,500-3,150 cal вP) (Fall et al. 1998; Berelov 2006). Regional differences in timing of the population change cause this difference in date between the Galilee and Dead Sea regions.

The two decreases in the oak pollen curve around 4,000 and 3,200 cal BP might be related to drought events (Langgut et al. 2013). At least the latter one is also to be seen in the Dead Sea record from Ein Gedi (Litt et al. 2012) as well as in the Dead Sea water level curve (Kushnir and Stein 2010; Stein et al. 2010), which correlates to the Late Bronze Collapse represented by the destruction of numerous urban centres in the Levant (Langgut et al. 2013). A dry event during the Late Bronze-Iron Age transition is also shown in high resolution records from the northern Levant (Kaniewski et al. 2010). Regarding the decreased tree pollen values in the Kinneret record around 4,000 cal BP (beginning of the Middle Bronze Age), it is uncertain whether or not this pollen signal is related to the so-called 4.2 cal kyr BP drought event between 4,200 and 3,900 cal BP (Weiss and Bradley 2001). In the Ein Gedi record there is no clear evidence that correlates with this event, which might be due to the lower sample resolution of 100 years. In the northern Levant, the vegetation of coastal Syria appears to have been more arid between 4,200 and 3,900 cal BP than is indicated on average in a pollen record published by Kaniewski et al. (2008). However, these authors emphasise that the 3.2 cal kyr BP 
Fig. 7 Correlation of pollen records showing a south-tonorth-transect along the Dead Sea Rift. a Dead Sea pollen record after Litt et al. (2012) plotted against reliable chronology and correlated to archaeological periods; b Lake Kinneret record (this study) plotted against reliable age model; $\mathbf{c}$ Birkat Ram pollen record after Schwab et al. (2004) plotted against depth $(\mathrm{cm})$ and supplemented by the tentative chronology; d Lake Hula pollen sequence after Baruch and Bottema (1999) plotted against depth $(\mathrm{cm})$ and supplemented by an estimated chronology after van Zeist et al. (2009). The upper coloured horizon indicates olive cultivation during the Hellenistic and Roman/ Byzantine periods. The lower coloured horizon indicates olive cultivation during the Chalcolithic period, Early Bronze Age (EBA) and Middle Bronze Age in the Dead Sea record, and during the Chalcolithic period and EBA in the other records, respectively. The grey bar shows a tentative correlation of similar vegetation patterns
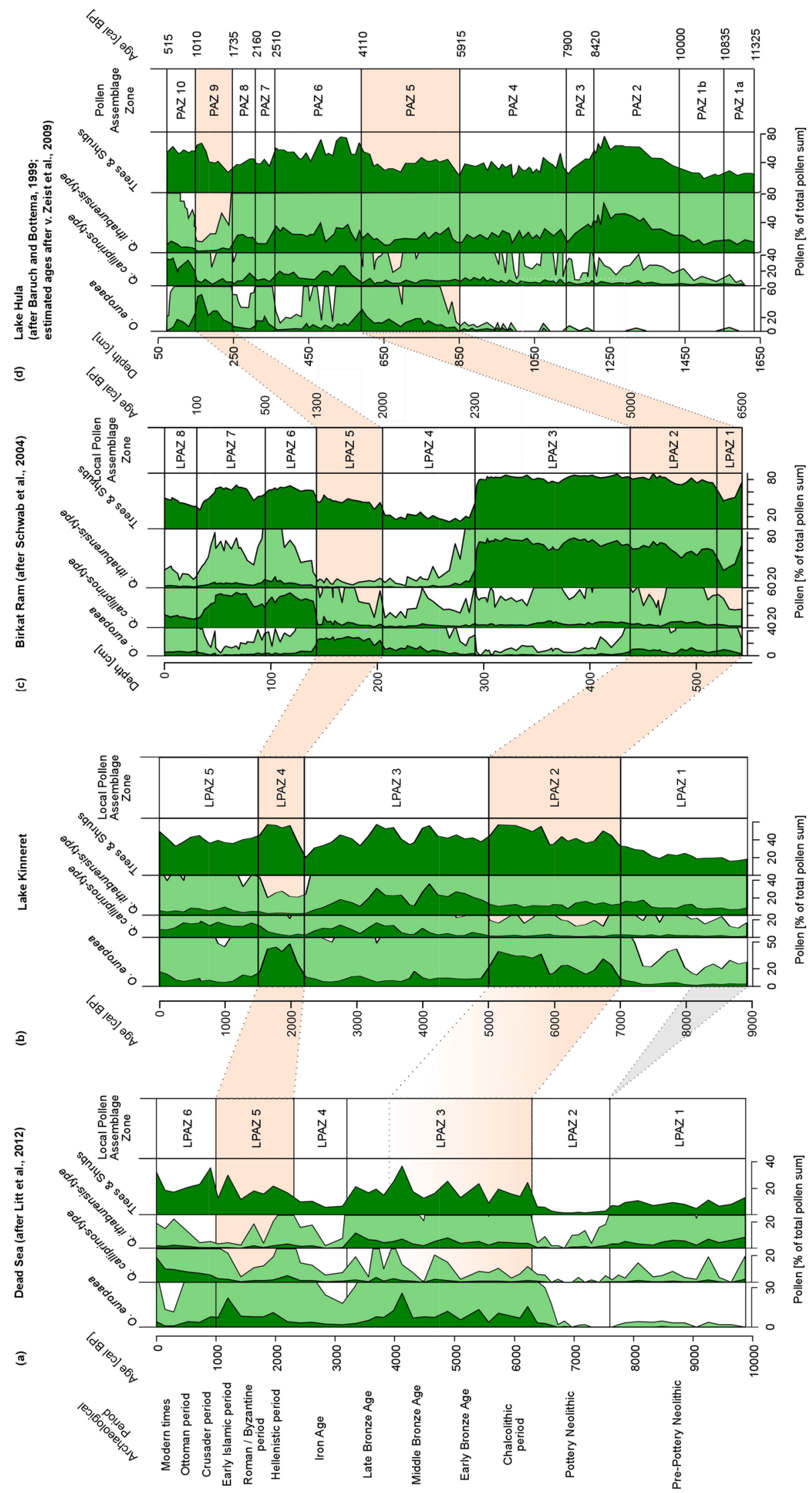
event was clearly dryer and lasted longer than the $4.2 \mathrm{cal}$ kyr event.

\section{2,300-1,500 cal BP (Hellenistic and Roman/ Byzantine periods)}

In the Kinneret record, the replacement of oak woodland by olive groves is obvious at the beginning of the Hellenistic period (Fig. 6). This is in agreement with the archaeological findings that important cities were established around the lake at that time, such as Hippos and Gadara as parts of the so-called Decapolis (Zangenberg and Busch 2003). In addition, during the Roman period, Tiberias was founded (Fortner 2003). Olive production played an enormous role as indicated by numerous archaeological finds of oil presses (Safrai 1994; Fortner and Rottloff 2003). The pattern of increased evidence of Olea is in good agreement with the pollen ratios recorded by Baruch (1986), who analysed sediment core KIN4D taken in 1979 from a more southern part of Kinneret. Since olive pollen ratios in the Birkat Ram record (Neumann et al. 2007a) do not rise as strongly as in the Kinneret record, the trade in olive oil is assumed to have been established in the Kinneret region earlier than on the Golan Heights (Zohary et al. 2012). High olive pollen values are typical through the Roman and Byzantine period, which can also be observed in the Birkat Ram record (Neumann et al. 2007a), in the Lake Hula results (van Zeist et al. 2009), as well as from Ein Gedi (Litt et al. 2012). During this period, the cultivation of Vitis vinifera (grapevine) and Juglans regia (walnut) is clearly shown in this region.

\section{1,500 cal BP: present (early Islamic period to present)}

After the abandonment of olive groves and the decline of economic structures during the early Islamic period (Safrai 1994), vacant land was re-occupied by evergreen oaks and pistachios, but deciduous oaks did not recover as strongly (LPAZ 5; Fig. 6). Compared to the tall $Q$. ithaburensis (Mount Tabor oak), the shrubby $Q$. calliprinos and P. lentiscus are less vulnerable to impact from humans and livestock, such as by grazing or cutting (Danin 1988; Baruch 1990). There are high values of Sarcopoterium spinosum throughout this period of woodland regeneration (Fig. 6). According to Danin (1999), this semi-shrub plays an important role in the plant succession in fallow fields at the centre of the Mediterranean territory of Israel.

A similar vegetational succession after the Olea decline is obvious in the records from Lake Hula (van Zeist et al. 2009), Birkat Ram (Neumann et al. 2007a), as well as the Dead Sea (Fig. 7; Litt et al. 2012). The original natural Mediterranean woodland mainly of deciduous oaks was replaced by macchia and batha evergreen scrub in the entire southern Levant between 1,500 and 1,000 cal вP. Macchia is characterized by $Q$. calliprinos and P. lentiscus, while batha (garrigue) is represented by $S$. spinosum-type in the pollen diagram. The uppermost distinct Pinus increase also reflects human impact on the vegetation, because the modern distribution of $P$. halepensis (Aleppo pine) is the result of the planting of woods at the beginning of the 20th century and does not represent the natural vegetation cover (Liphschitz and Biger 2001).

\section{Conclusions}

A new pollen record from the deepest part of Lake Kinneret recording the last 9,000 years fills a gap in the vegetation history of the southern Levant between the Dead Sea in the south of Israel and the Golan Heights in the north (Fig. 1). It is the longest continuous Holocene pollen record from this basin obtained to date, which allows reconstruction of the environmental history of this area, including human impact, since the Neolithic. With an excellent chronology from numerous AMS radiocarbon dates the Kinneret results can serve as a palynological reference section for the Lower Galilee region as part of the Mediterranean vegetation territory. The Kinneret record is strongly influenced by indicators of human activity in the pollen diagram, especially during the Chalcolithic/Early Bronze Age, the Hellenistic-RomanByzantine periods and in modern times. The first Olea pollen increase as early as the transition between the Late Neolithic and the Early Chalcolithic periods from ca. 7,000 cal years BP onward is remarkable, which is several centuries earlier than in the well-dated Ein Gedi pollen record, Dead Sea (Fig. 7). The new data from Kinneret underline the assumption that Lower Galilee was a centre of early olive cultivation in the Levant. The second prominent Olea phase during the Hellenistic/Roman/Byzantine period in the Kinneret record is almost simultaneous with other well-dated pollen records in the southern Levant. The Mediterranean macchia and batha scrub, as known today, has developed as the result of human impact in Lower Galilee since the last ca. 1,500 years.

Acknowledgements This study is a contribution to the Collaborative Research Centre project CRC 806 "Our Way to Europe", funded by the Deutsche Forschungsgemeinschaft (DFG; German Research Foundation). We thank Patricia Roeser, Georg Heumann, Sven Olver Franz (Bonn), Michael Köhler (Potsdam), and Mordechai Stein (Jerusalem) for their support during the fieldwork in 2010. In addition, we thank Andrea Miebach, Nadine Pickarski and Hannah Vossel (Bonn) for constructive discussions and help to improve the text and the figures. In addition, we acknowledge the critical comments of two anonymous reviewers.

Open Access This article is distributed under the terms of the Creative Commons Attribution 4.0 International License (http://creativecommons.org/licenses/by/4.0/), which permits unrestricted use, 
distribution, and reproduction in any medium, provided you give appropriate credit to the original author(s) and the source, provide a link to the Creative Commons license, and indicate if changes were made.

\section{References}

Ahlström GW, Rollefson GO (1993) The history of ancient Palestine from the palaeolithic period to Alexander's conquest. Sheffield Academic Press, Sheffield

Baruch U (1986) The late Holocene vegetational history of Lake Kinneret (sea of Galilee), Israel. Paléorient 12:37-47

Baruch U (1990) In: Palynological evidence of human impact on the vegetation as recorded in Late Holocene lake sediments in Israel. In: Bottema S, Entjes-Nieborg G, van Zeist W (eds) Man's role in the shaping of the eastern Mediterranean Landscape. Balkema, Rotterdam, pp 283-293

Baruch U, Bottema S (1999) A new pollen diagram from Lake Hula: vegetational, climatic and anthropogenic implications. In: Kawanabe H, Coulter GW, Roosevelt AC (eds) Ancient lakes: their cultural and biological diversity. Kenobi Productions, Ghent, pp 75-86

Bar-Yosef O (1995) Earliest food producers: pre-pottery neolithic (8000-5500). In: Levy T (ed) The archaeology of society in the holy land. Leicester University Press, London, pp 190-204

Bar-Yosef O, Belfer-Cohen A (1992) From foraging to farming in the Mediterranean Levant. In: Gebauer AG, Price TD (eds) Transition to agriculture in prehistory. Prehistoric Press, Madison, pp 21-48

Berelov I (2006) Signs of sedentism and mobility in an agro-pastoral community during the Levantine Middle Bronze Age: interpreting site function and occupation strategy at Zahrat adh-Dhra' 1 in Jordan. J Anthropol Archaeol 25:117-143. https://doi.org/10.1016/j. jaa.2005.09.001

Beug H-J (2004) Leitfaden der Pollenbestimmung für Mitteleuropa und angrenzende Gebiete. Pfeil, München

Bitan A (1974) The wind regime in the north-west section of the Dead Sea. Theor Appl Climatol 22:313-335. https://doi.org/10.1007/ bf02246585

Bitan A (1981) Lake Kinneret (Sea of Galilee) and its exceptional wind system. Bound Layer Meteorol 21:477-487. https://doi. org/10.1007/bf02033595

Blaauw M (2010) Methods and code for "classical" age-modelling of radiocarbon sequences. Q Geochronol 5:512-518. https://doi. org/10.1016/j.quageo.2010.01.002

Boucher K (1975) Global climate. English Universities Press, London

Danin A (1988) Flora and vegetation of Israel and adjacent areas. In: Yom Tov Y, Tchernov E (eds) The zoogeography of Israel. Junk Publishers, Dordrecht, pp 129-159

Danin A (1999) The main vegetation types of Israel. In: Danin A, Orshan G (eds) Vegetation of Israel, vol 1. Desert and coastal vegetation. Backhuys Publishers, Leiden, pp 19-32

Danin A, Plitmann U (1987) Revision of the plant geographical territories of Israel and Sinai. Plant Syst Evol 156:43-53. https://doi. org/10.1007/bf00937200

Faegri K, Iversen J (1989) Textbook of pollen analysis. In: Faegri K, Kaland PE, Krzywinski K (eds), 4th edn. Wiley, Chichester

Fall PL, Lines L, Falconer SE (1998) Seeds of civilization: Bronze Age rural economy and ecology in the southern Levant. Ann Assoc Am Geogr 88:107-125. https://doi.org/10.1111/1467-8306.00087

Finkelstein I, Halpern B, Lehmann G, Niemann HM (2006) The Megiddo hinterland project. In: Finkelstein I, Ussishkin D, Halpern B (eds) Megiddo IV: The 1998-2002 seasons. (Monograph
Series of the Institute of Archaeology of Tel Aviv University 24). Tel Aviv University, Tel Aviv, pp 705-776

Fortner S (2003) Tiberias-Eine Stadt zu Ehren des Kaisers. In: Faßbeck G, Fortner S, Rottloff A, Zangenberg J (eds) Leben am See Gennesaret. von Zabern, Mainz, pp 86-92

Fortner S, Rottloff A (2003) Fisch, Flax und Öl. Wirtschaftliches Leben und Handel rund um den See Gennesaret in hellenistisch-römischer Zeit. In: Faßbeck G, Fortner S, Rottloff A, Zangenberg J (eds) Leben am See Gennesaret. von Zabern, Mainz, pp 130-137

Galili E, Stanley DJ, Sharvit J, Weinstein-Evron M (1997) Evidence for earliest olive-oil production in submerged settlements off the Carmel coast, Israel. J Arch Sci 24:1:1,141-1,150

Garfinkel Y, Klimscha F, Shalev S, Rosenberg D (2014) The beginning of metallurgy in the southern Levant: a late 6th millennium Cal BC copper awl from Tel Tsaf, Israel. PLoS One 9:e92591

Geyh MA, Schotterer U, Grosjean M (1998) Temporal changes of the (super 14) C reservoir effect in lakes. Radiocarbon 40:921-931. https://doi.org/10.2458/azu_js_rc.40.3770

Grimm EC (1987) CONISS: a FORTRAN 77 program for stratigraphically constrained cluster analysis by the method of incremental sum of squares. Comput Geosci 13:13-35

Hajar L, Haidar-Boustani M, Khater C, Cheddadi R (2010) Environmental changes in Lebanon during the Holocene: man vs. climate impacts. J Arid Environ 74:746-755

Hajar L, Khater C, Cheddadi R (2008) Vegetation changes during the late Pleistocene and Holocene in Lebanon: a pollen record from the Bekaa Valley. Holocene 18:1,089-1,099

Hazan N (2004) Lake Kinneret levels and active faulting in the Tiberias area. Isr J Earth Sci 53:199-205

Hazan N, Stein M, Agnon A, Marco S, Nadel D, Negendank JFW, Schwab MJ, Neev D (2005) The late Quaternary limnological history of Lake Kinneret (Sea of Galilee). Isr Q Res 63:60-77. https://doi.org/10.1016/j.yqres.2004.09.004

Heim C, Nowaczyk NR. Negendank JFW, Leroy SAG, Ben-Avraham Z (1997) Near East desertification: evidence from the Dead Sea. Naturwissenschaften 84:398-401

Horowitz A (1979) The quaternary of Israel. Academic Press, New York

Israel Oceanographic and Limnological Research (2017) https://isramar.ocean.org.il/isramar2009/DeadSea/LongTerm.aspx

Jaffe S (1988) Climate of Israel. In: Yom Tov Y, Tchernov E (eds) The zoogeography of Israel. Junk, Dordrecht, pp 79-95

Kaniewski D, Paulissen E, Van Campo E, Al-Maqdissi M, Bretschneider J, Van Lerberghe K (2008) Middle East coastal ecosystem response to middle-to-late Holocene abrupt climate changes. PNAS 105:13,941-13,946

Kaniewski D, Paulissen E, Van Campo E, Weiss H, Otto T, Bretschneider J, Van Lerberghe K (2010) Late second-early first millennium BC abrupt climate changes in coastal Syria and their possible significance for the history of the Eastern Mediterranean. Q Res $74: 207-215$

Kaniewski D, Van Campo E, Boiy T, Terral J-F, Bouchaib K, Besnard G (2012) Primary domestication and early uses of the emblematic olive tree: palaeobotanical, historical and molecular evidence from the Middle East. Biol Rev 87:885-899

Karmon Y (1994) Israel: Eine geographische Landeskunde. Wissenschaftliche Buchgesellschaft, Darmstadt

Kislev ME (1994-1995) Wild olive stones at submerged Chalcolithic Kfar Samir, Haifa, Israel. J Isr Prehist Soc 26:134-145

Kushnir Y, Stein M (2010) North Atlantic influence on 19th-20th century rainfall in the Dead Sea watershed, teleconnections with the Sahel, and implication for Holocene climate fluctuations. Q Sci Rev 29:3,843-3,860

Langgut D, Finkelstein I, Litt T (2013) Climate and the Late Bronze collapse: new evidence from the southern Levant. Tel Aviv 40:149-175 
Langgut D, Neumann FH, Stein M, Wagner A, Kagan EJ, Boaretto E, Finkelstein I (2014) Dead Sea pollen record and history of human activity in the Judean Highlands (Israel) from the Intermediate Bronze into the Iron Ages (ca 2500-500 BCE). Palynology 38:280-302

Lev L, Boaretto E, Heller J, Marco S, Stein M (2007) The feasibility of using Melanopsis shells as radiocarbon chronometers, Lake Kinneret, Israel. Radiocarbon 49:1,003-1,015. https://doi. org/10.2458/azu_js_rc.49.2993

Liphschitz N, Biger G (2001) Past distribution of Aleppo pine (Pinus halepensis) in the mountains of Israel (Palestine). Holocene 11:427-436. https://doi.org/10.1191/095968301678302869

Litt T, Ohlwein C, Neumann FH, Hense A, Stein M (2012) Holocene climate variability in the Levant from the Dead Sea pollen record. Q Sci Rev 49:95-105. https://doi.org/10.1016/j. quascirev.2012.06.012

Miebach A, Chen CZ, Schwab MJ, Stein M, Litt T (2017) Vegetation and climate during the Last Glacial high stand (ca. 28-22 ka BP) of the Sea of Galilee, northern Israel. Q Sci Rev 156:47-56

Migowski C, Agnon A, Bookman R, Negendank JFW, Stein M (2004) Recurrence pattern of Holocene earthquakes along the Dead Sea Transform revealed by varve-counting and radiocarbon dating of lacustrine sediments. Earth Planet Sci Lett 222:301-314

Migowski C, Stein M, Prasad S, Negendank JFW, Agnon A (2006) Holocene climate variability and cultural evolution in the Near East from the Dead Sea sedimentary record. Q Sci Rev 23:1,723-1,731

Moore PD, Webb JA, Collinson ME (1991) Pollen analysis, 2nd edn. Blackwell, Oxford

Murphy MA, Salvador A (1999) Special-International Stratigraphic Guide-an abridged version. Epis Newsmag Int Union Geol Sci 22:255-271

Namdar D, Amrani A, Nimrod G, Milevski I (2015) Olive oil storige during the fifth and sixth millenia $\mathrm{BC}$ at Ein Zippori, Northern Israel. Isr J Plant Sci 63:65-74

Neef R (1990) Introduction, development and environmental implications of olive culture: the evidence from Jordan. In: Bottema S, Entjes-Nieborg G, Van Zeist W (eds) Mans role in the shaping of the Eastern Mediterranean Landscape. Balkema, Rotterdam, pp 295-306

Neumann FH, Kagan EJ, Leroy SAG, Baruch U (2010) Vegetation history and climate fluctuations on a transect along the Dead Sea west shore and their impact on past societies over the last 3500 years. J Arid Environ 74:756-764

Neumann FH, Kagan EJ, Schwab M, Stein M (2007b) Palynology, sedimentology and palaeoecology of the late Holocene Dead Sea. Q Sci Rev 26:1,476-1,498

Neumann F, Schölzel C, Litt T, Hense A, Stein M (2007a) Holocene vegetation and climate history of the northern Golan heights (Near East). Veget Hist Archaeobot 16:329-346. https://doi.org/10.1007/ s00334-006-0046-x

Nishri A, Stiller M, Rimmer A, Geifman Y, Krom M (1999) Lake Kinneret (The Sea of Galilee): the effects of diversion of external salinity sources and the probable chemical composition of the internal salinity sources. Chem Geol 158:37-52. https://doi. org/10.1016/s0009-2541(99)00007-8

Reille M (1992) Pollen et spores d'Europe et d'Afrique du nord. Laboratoire de Botanique Historique et Palynologie, Marseille

Reimer PJ, Baillie MGL, Bard E et al (2009) IntCal 09 and Marine09 radiocarbon age calibration curves, $0-50,000$ years cal BP. Radiocarbon 51:1,111-1,150

Rohling EJ, Hayes A, Mayewski PA, Kucera M (2009) Holocene climate variability in the eastern Mediterranean, and the end of the Bronze Age. In: Bachhuber C, Roberts G (eds) Forces of transformation: the end of the Bronze Age in the Mediterranean. Oxbow, Oxford, pp 2-5
Rohling EJ, Palike H (2005) Centennial-scale climate cooling with a sudden cold event around 8,200 years ago. Nature 434:975-979

Rollefson GO, Köhler-Rollefson I (1992) Early Neolithic exploitation patterns in the Levant: cultural impact on the environment. Popul Environ 13:243-254. https://doi.org/10.1007/ BF01271025

Rossignol-Strick M (1995) Sea-land correlation of pollen records in the eastern Mediterranean for the glacial-interglacial transition: biostratigraphy versus radiometric time-scale. Q Sci Rev 14:893915. https://doi.org/10.1016/0277-3791(95)00070-4

Safrai Z (1994) The economy of Roman Palestine. Routledge, London

Schwab MJ, Neumann F, Litt T, Negendank JFW, Stein M (2004) Holocene palaeoecology of the Golan Heights (Near East): investigation of lacustrine sediments from Birkat Ram crater lake. Q Sci Rev 23(1):1,723-1,731. https://doi.org/10.1016/j. quascirev.2004.05.001

Sharon D, Kutiel H (1986) The distribution of rainfall intensity in Israel, its regional and seasonal variations and its climatological evaluation. J Climatol 6:277-291. https://doi.org/10.1002/ joc. 3370060304

Stein M, Torfstein A, Gavrieli I, Yechieli Y (2010) Abrupt aridities and salt deposition in the post-glacial Dead Sea and their North Atlantic connection. Q Sci Rev 29:567-575

Steininger FF, Piller WE (1999) Empfehlungen (Richtlinien) zur Handhabung der stratigraphischen Nomenklatur. Courier Forschungsinstitut Senckenberg 209:1-19

Stiller M, Carmi I, Kaufman A (1988) Organic and inorganic 14C concentrations in the sediments of lake Kinneret and the Dead Sea (Israel) and the factors which control them. Chem Geol Isot Geosci Sect 73:63-78. https://doi.org/10.1016/0168-9622(88)90021-8

Stiller M, Kaufman A, Carmi I, Mintz G (2001) Calibration of lacustrine sediment ages using the relationship between $14 \mathrm{C}$ levels in lake waters and in the atmosphere: the case of Lake Kinneret. Radiocarbon 43:821-830

Stuiver M, Polach HA (1977) Discussion: reporting of C-14 data. Radiocarbon 19:355-363. https://doi.org/10.2458/azu_js_rc.19.493

Van Zeist W, Baruch U, Bottema S (2009) Holocene palaeoecology of the Hula area, northeastern Israel. In: Kaptijn E, Petit LP (eds) A timeless vale. (Archaeological Studies Leiden University 19). Leiden University Press, Leiden, pp 29-64

Van Zeist W, Bottema S (1991) Late quaternary vegetation of the Near East. Reichert, Wiesbaden

Weiss E (2015) "Beginning of the fruit growing in the Old World"two generations later. Isr J Plant Sci 62:75-85

Weiss H, Bradley RS (2001) What drives societal collapse? Science 291:609-610

Yasuda Y, Kitagawa H, Nakagawa T (2000) The earliest record of major anthropogenic deforestation in the Ghab Valley, northwest Syria: a palynological study. Q Int 73-74:127-136. https://doi. org/10.1016/S1040-6182(00)00069-0

Zangenberg J, Busch P (2003) Hippos und Gadara - Ein Hauch von Welt am See. In: Faßbeck G, Fortner S, Rottloff A, Zangenberg J (eds) Leben Am See Gennesaret. von Zabern, Mainz, pp 117-129

Zohary M (1962) Plant life of Palestine-Israel and Jordan. Ronald, New York

Zohary M (1982) Vegetation of Israel and adjacent areas. Reichert, Wiesbaden

Zohary D, Hopf M, Weiss E (2012) Domestication of plants in the Old World: the origin and spread of domesticated plants in southwest Asia, Europe, and the Mediterranean basin, 4th edn. Oxford University Press, Oxford

Zwickel W (2003) Städte, Gräber, Handelsrouten—Die Bronzezeit am See Gennesaret. In: Faßbeck G, Fortner S, Rottloff A, Zangenberg J (eds) Leben Am See Gennesaret. von Zabern, Mainz, pp 18-24 